\title{
수면호흡장애(총론)
}

부산대학교 의과대학 이비인후과학교실

노 환 중

\section{Sleep Disordered Breathing}

Hwan-Jung Roh, MD

Department of Otolaryngology, College of Medicine, Pusan National University, Busan, Korea

\section{수면호흡장애의 개요}

수면호흡장애( sleep disordered breathing, SDB) 란 잠을 자는 동안 상기도의 저항이 증가하면서 일어나는 호 흡의 이상을 통틀어 이야기하는 것으로 단순코골이, 상 기도 저항증후군, 폐쇄성수면무호흡증, 중추성무호흡, 저 호흡을 포함하고 있다.

국내에서는 지난 10 여 년간 LAUP가 먼저 소개되면 서 코골이에만 초점이 맞추어져 온 것이 사실이다. 이후 LAUP의 한계를 알게 되면서 수면무호흡에 관심을 가지 게 되었지만, 수면호흡장애의 개념 없이 수술에만 초점 을 맞추어 수면무호흡증을 이해하려고 해왔다.

수면호흡장애의 치료는 수면호흡장애를 초래하는 질 환을 정확히 인식하고 각 환자에 맞는 치료법을 선택해 야 한다. 또한 수면 중 어떤 일이 일어나는지 객관적으 로 기록 분석하는 수면다원검사의 이해가 선행되어야 한다.

다양한 치료법이 있음에도, 이비인후과 의사들은 주로 수술적 해법만을 찾아온 것이 사실이다. 이비인후과 의 사들이 수술 외에도 다른 치료법을 이해함으로써, 보다 환자에게 맞는 적합한 치료를 할 수 있고 이에 따라 환

교신저자 : 노환중, 602- 739 부산광역시 서구 아미동 1 가 10 번지 부산대학교 의과대학 이비인후과학교실 전화 :(051) 240-7333. 전송 :(051) 248- 1248 E-mail :rohhj@pusan.ac.kr
자의 만족도가 높아 질 수 있다.

본 총론에서는 폐쇄성 수면호흡장애의 종류와 치료 전 반에 대하여 기술하고자 한다.

\section{수면호흡장애(SDB) 역사와 용어의 정의}

수면호흡장애에 대한 관심은 1965년 Gastaut 등에 의 해 뚱뚱하고 낮에 졸린 사람에게서 야간수면검사 때 이 상호흡장애를 일으키는 것을 객관적으로 입증하여“ Pickwickian Syndrome"으로 명명하면서 시작되었다. ${ }^{1)}$

1972년 뚱뚱하면서 주간 졸림이 있는 질환에 대해 처 음 국제모임이 있었고, 여기에서 Guilleminault 등이 불 면증처럼 야간수면이 방해 받으면 뚱뚱하지 않은 환자 도 폐쇄성무호흡이 있다고 보고하였다. ${ }^{2-}$ ) 이후 비만하 지 않은 어린이에서“ 과수면 증후군”에 관한 보고가 있 었고, 기관절개술이 고혈압을 정상화 시킨 보고가 이어 졌다. ${ }^{6-10)}$

이후 부분적 혹은 일시적으로 상기도가 좁아진 환자에 서, 무호흡이나 저호흡 및 산소포화도 감소 없이도 숨쉬 기 위한 노력이 증가된다는 사실이 밝혀 졌다. 주간 졸 림이 있으면서 상기도 저항이 증가하고 이에 동반한 뇌 파상 각성이 있는 경우를 1993년 Guilleminault 등이 처음으로" 상기도저항증후군"으로 명명하였다. ${ }^{31)} \mathrm{Ame-}$ rican A ssociation of Sleep Medicine( A ASM) 은 이를 respiratory effort related arousal(RERA)라고 정의 하였다. ${ }^{37)}$ 이는 10 초 이상 지속되고 점차 식도압력이 
음압을 나타내고, 각성과 동시에 증가된 음압이 회복되 는 양상을 나타낸다.

무호흡지수(apnea index, Al) 는 잠자는 동안 시간당 무호흡 횟수로 정상 상한치는 5 로 정의되었다. ${ }^{11)} 1990$ 년에 Gould 등이 주간졸림을 동반한 폐쇄성수면무호흡 환자에서 저호흡(hypopnea) 이 있다는 보고 이후, 무호 흡지수 보다는 RDI( respiratory disturbance index)로 알려진 무호흡저호흡지수( apnea- hypopnea index, $\mathrm{AHI})$ 가 이 질환을 설명하는 기준이 되었다. Flow limitation 개념이 정립되면서 2005년 AASM은 RDI를 $\mathrm{AHI}+\mathrm{RERA}$ 로 강화하였다. 따라서 이제는 RDI와 AHI 를 동일하게 보지 않는다.

현재 사용하는 경도, 중등도, 중증의 구분이 때로는 애매한 경우가 많다. A A SM의 T ask Force팀이 A HI가 시간당 15 30을 중등도(moderate) 로 규정하였고, 시 간당 $\mathrm{AHI}$ 가 30 이상을 중증(severe)으로 규정하였 다. ${ }^{12)}$

\section{수면호흡장애의 유병률}

성인에 있어서 코골이는 40 60\% 의 유병률이 있지 만, $^{13)}{ }^{14)}$ 폐쇄성 수면무호흡의 유병률은 상당히 낮고, 연 구에 따라 다양한 것으로 보고되고 있다. 1993년 Young 등에 의해 30 60세 군에서 AHI가 5 이상인 경우는 남자 $24 \%$, 여자 $9 \%$ 로 보고 되었지만, 주간 졸 림을 동반하는 폐쇄성 수면무호흡증의 경우는 남녀 각 각 $4 \%$ 와 $2 \%$ 로 보고 되었다. ${ }^{15)}$

폐쇄성 수면무호흡증의 위험성은 40대에서 60대 사 이에 최고치를 보이고 비만과 남성에 강한 상관 관계가 있다. ${ }^{16)} \mathrm{BMI}$ 가 29 이상인 사람은 BMI가 25 이하인 사 람보다 폐쇄성 수면무호흡증이 있을 가능성이 8 12배 증가한다. 복부비만인 사람은 상기도 지방축척으로 이어 져 상기도가 좁아지고 넓게 유지 되지 못하며, 저환기를 초래한다. ${ }^{17) 18)}$ 폐경기 이후의 여성은 남성과 유사한 유 병률을 갖게 된다. ${ }^{19-23)}$

여러 다른 요소 즉 기도확장근육의 활동성, 악안면골 격구조, 동반질환, 담배, 술, 안정제 등의 환경적 요소들 도 무호흡에 영향을 미친다.

\section{수면호흡장애의 종류}

\section{단순 코골이(Simple snoring)}

코를 고는 환자 중에 주간증상(졸림 이나 피로감, 두 통) 이 없고 이학적 검사상 뚜렷한 해부적 폐쇄 부위가 없으며, 교감신경의 활동 증가 소견이 없는 경우를 양성 코골이 혹은 단순 코골이라고 정의한다.

\section{상기도저항증후군(Upper airway resistance syndrome, UARES)}

상기도저항증후군은 수면과 연관된 호흡장애로 주간졸 림, 피로 등을 일으키는 증상 집합체이다. 자는 동안 상 기도 저항이 증가되고 흡기시 식도 압력(negative peak end) 증가와 잦은 각성(arousal) 이 일어난다. 이는 잘 알려진 수면무호흡증과 달리 새롭게 기술된 질환군이다. 남녀성비는 차이가 없으며, 정확한 유병률은 알려져 있 지 않다. ${ }^{31)}$ 무호흡증에 비해 상대적으로 젊은 연령에 많 으며 얕은 잠을 자며 많은 뒤척임을 호소하고, 때때로 수면 중 땀이 많거나, 손발이 차고, 체위변화에 따른 어 지러움증을 호소하기도 한다. 이 증상들은 주로 상기도 저항을 극복하기 위해 숨을 들이마시는 노력이 증가하게 되고 이로 인해 수면이 방해를 받아 분절(fragmentation) 이 생겨 발생한다. 모든 경우에 코를 고는 것은 아니며, 구개성형술로 코골이가 없어지는 경우에도 실제로 상기 도저항증후군은 남아있는 경우가 많다. ${ }^{33)}$ 다른 증상으로 는 입마름, 침흘림, 잦은 인후통증, 기상 시 두통 등이 있다. 상기도저항증후군은 어린이들에서도 가끔 확인되 지만 흔히 의사들이 간과하는 경우가 많았다. 이유는 연 령에 따라 증상이 다양하게 나타나며, 수면호흡장애의 다 른 질환에서 나타나는 증상과 구분하기 쉽지 않기 때문 이다. ${ }^{32)}{ }^{34)}$

잠자는 동안에 식도압력검사가 상기도저항증후군을 진 단하는 데 가장 확실한 방법이다. ${ }^{36)}$ 야간수면다원검사상 $\mathrm{RDI}$ 는 정상이며, flow limitation에 따른 반복되는 식도 압력 증가와 호흡노력의 증가로 각성(RERA)이 일어나 게 된다. ${ }^{37)}$ 대부분 cephalometry 나 상기도 내시경검사 시 좁아진 상기도, 특히 혀 뒷부분이 좁아진 소견을 보 인다. ${ }^{31)}$ 
증가된 상기도 저항으로 인하여 숨쉬기 위한 노력은 수초 동안 진행되는 각성을 유발하고, 이것이 수면을 조 각나게 하여 주간졸림이 나타난다. UARS와 고혈압은 관 계가 많다. ${ }^{35) 38-40)}$ Silverberg와 Oksenberg는 OSAS 환자의 30 40\% 가 고혈압이었고, 무호흡증 없는 코골이 환자의 30 75\% 환자가 이상혈압이었다고 보고하였다. ${ }^{43)}$

치료는 확진 및 증상의 개선을 위해 CPAP이 초창기 에 사용되었다. Rauscher 등은 RDI가 5 이하이고 코를 골며 각성지수가 $20 \pm 10 / \mathrm{hr}$ 인 환자에서 CPAP을 사용 한 결과 이중 $19 \%$ 만이 6 개월 이상 매일 사용하였으며 이중 $73 \%$ 에서 주간졸림이 감소하였다고 보고하였다. ${ }^{41}$ 수술은 Powell 등이 연구개에 대한 고주파술( somnoplasty) 를 이용하여 14 명의 UARS 환자와 7 명의 mild OSA 환자에게 시행하여 수면효율과 식도압력감소, 과도 한 주간졸음, 주관적 콧소리가 전체 환자에서 감소한 것 으로 보고하였다. ${ }^{42}$

하지만 아직 UARS에 대한 치료는 확립되지 않은 상 태로 많은 연구가 필요한 실정이다.

폐쇄성 수면무호흡증(Obstructive sleep apnea syndrome, OSAS)

OSAS는 잠자는 동안에 반복적으로 상기도가 막히는 현상이 일어나면서, 산소포화도가 떨어지고 큰 코골이를 동반하며 수면의 단절과 주간졸림이 일어나는 질환이다. 야간증상은 코골이, 질식감, 조이는 느낌, 뒤척이는 잠 등이다. 코골이가 병원을 찾는 가장 흔한 증상이다. 이 는 사춘기 때 시작하여 체중 증가와 함께 강도가 강해 지는 경향이 있다. 이는 가족간의 불협화음을 유발하고 심지어 각방을 쓰게 된다. 코골이는 앙와위( supine position) 에서 심해지며, 음주나 안정제에 의해 더욱 악화된 다. 가끔 환자는 무호흡에 따른 질식감에 의해 깨어나게 되고 심한 경우 깨어나서 숨을 들이마시지 못하고 기침 한 후 회복되는 경우도 있다. 종종 동침자에 의해 무호 흡이 관찰된다. 환자는 많이 뒤척이고 개운하지 않은 잠 을 자게 된다. 이는 상기도가 막혀 잠이 조각나는 현상 을 일으키며, 무호흡이 뇌파상 잦은 각성으로 종료되는 현상으로 나타난다. 부분적으로 잠에서 깨어 잠꼬대를 하 거나 혹은 갑자기 일어났다 잠에 다시 빠지기도 하고, 완 전히 깨어 잠에 다시 들지 못하기도 한다. 이 불면증 형
태는 경도 때 많이 나타나며 주로 초기에 나타난다. 위 의 압력을 증가시켜 가슴의 작열감이나 위산역류증상을 일으킨다. 아주 드문 경우에서 후두경련(lary ngeal sp$\mathrm{asm})$ 이 발생한다. 심한 발한이 $66 \%$ 에서 보고되었다. ${ }^{26)}$ 입마름, 침흘림, 아침에 두통, 인후통, 야뇨증 등을 호소 한다. ${ }^{24) 25)}$

주간증상으로는 피곤하거나 지치는 현상이 주된 증상 이다. 과다주간졸음( excessive day time sleepiness) 은 야간의 수면단절에 의해 일어나며 환자는 주로 낮에 졸 린 것을 부정하지만, 배우자 등에게 조용한 상태(책 읽 을 때, TV 볼 때, 차 탈 때 등) 에서 조는 가를 물어 확 인할 수 있다. 운전 중 조는 것은 아주 치명적인 결과를 낼 수 있다. ${ }^{27-30)}$ 인지장애 즉 기억력장애, 판단력장애, 집중력장애 등이 흔히 나타나며, 이는 일의 능률을 떨어 뜨려 업무에 지장을 줄 수 있다. 인격장애 즉 부산하거 나, 걱정, 우울증 증세 등을 보이고, 아침에 심한 혼돈 (confusion) 상태가 보고 된 적도 있다. ${ }^{26)}$

기타 증상으로는 성욕감퇴 또는 발기부전을 보이기도 하고, 심혈관계 합병증으로 인한 고혈압, 부정맥, 심허혈 증상을 보인다. 또한 자율 신경계증상으로 어지러움증이 나 손발이 찬 증상을 호소하기도 한다.

\section{수면호흠장애의 치료원칙}

\section{치료 목적}

코골이나 무호흡증 등 야간에 나타나는 증상뿐만 아 니라 주간졸음, 기상 시 두통, 집중력장애, 기억력감퇴, 학 습능력 저하, 만성 피로감 등의 주간증상을 함께 개선하 고 장기적으로 고혈압, 뇌졸중, 폐성고혈압, 심부정맥 등 심혈관계 합병증을 방지 할 수 있게 치료하는 것을 목 적으로 한다.

\section{치료 방법을 선택하는 데 기준이 되는 요소들}

폐쇄성 수면무호흡증 환자의 치료에서 가장 어려운 결 정은" 어떤 치료방법을 선택하는가?"이다. 원칙은 내과 적 치료 특히 지속적양압술이 기본이 되지만, 수면을 전 공하는 많은 의사들은 지속적양압술에 순응도가 낮은 환 자군이나 경도의 환자군에게 지속적양압술 혹은 구강내 장치 등 내과적 치료를 계속 할 것 인지 아니면 수술 치 
료를 할 것인지를 고민을 해왔다.

폐쇄성 수면무호흡증의 치료 방법을 선택하는 데 기준 이 되는 요소들은 1) 폐쇄를 일으키는 상기도의 해부학 적인 위치, 2) 환자의 체형(키, 체중, 목둘레), 3) 수면 다원검사상 폐쇄성 수면무호흡증의 심한 정도, 4) 환자 의 바람과 선호도, 5) 환자의 연령 및 건강 상태 등이다.

기도 폐쇄를 일으키는 해부학적인 위치가 광범위 하거 나 확실하지 않을 때는 지속적양압술이 주가 되지만, 확 실한 상기도 폐쇄부위가 있다면 수술을 염두에 두어야 한다.

환자의 체형에 따른 치료방법의 선택은 환자의 신체질 량지수(body mass index, $\mathrm{BMI}$ )와 목둘레 길이에 따라 결정한다. 신체질량지수는 키 제곱 미터당 몸무게 $(\mathrm{Kg})$ 로 정상이 25 이하이다. 신체질량지수가 높을수록 수술의 결 과가 좋지 않으므로 지속적양압술 치료를 우선한다. 또한 목둘레가 $43 \mathrm{~cm}$ 까지가 정상) 두꺼울수록 폐쇄성 수면무 호흡증의 정도가 심하므로 내과적 치료를 우선시 한다.

수면다원검사상 수면무호흡의 심한 정도가 경도(무호 흡저호흡지수 15 이하) 와 중등도 ( 무호흡저호흡지수 15 30 ) 인 경우는 중증( 무호흡저호흡지수 30 이상) 인 경우 보다 수술에 예후가 좋은 것으로 되어있다. 무호흡의 심 한 정도는 치료 방법의 결정에도 영향을 미치지만, 수술 방법을 결정하는 데도 영향을 미친다. 즉 정도가 심할수 록 더욱 적극적이고 광범위한 부위에 대한 수술 방법을 선택해야 한다.

가장 중요한 요소는 환자가 어떠한 치료를 원하는 가 이다. 환자에게 충분한 자료를 제시하고 이해를 시킨 후 에 환자의 결정을 존중해야 한다. 예로서 경도의 수면무 호흡이 있는 환자가 수술을 원하지 않을 경우 구강내장 치를 선택할 수 있다. 또한 지속적양압술을 사용 중인 환 자가 순응도에 문제가 있어 더 이상 사용을 하지 못하게 되는 경우에는 수술을 정도에 따라 선택한다.

마지막으로 중요한 인자가 환자의 건강 상태와 연령이 다. 특히 젊은 연령층의 경우 삶의 질을 고려하여 보다 적 극적인 수술 치료를 권유한다. 또한 수술의 좋은 대상이 되더라도 수술을 받기에 건강하지 못한 경우는 내과적 치 료를 할 수 밖에 없으며, 수술 방법의 선택에서도 나이에 영향을 받는다. 예로 설근부가 기도 폐쇄의 원인인 경우 젊은 사람은 여러 가지 방법을 택할 수 있으나, 혀의 탄
력성이 떨어진 나이든 경우는 선택의 폭이 제한된다.

\section{수술 결정시 고려해야 할 특성}

수술 방법의 선택 전에 고려해야 할 것들은 수면호흡장 애의 이해이다. 특히 단순 코골이를 먼저 생각하기 보다 는 폐쇄성 수면무호흡증과 상기도저항증후군을 포함한 전 반적인 수면호흡장애 이해가 치료방법선택에 중요하다.

또한 다른 수술과 달리 수면장애에 대한 수술은 단순 한 부위별 수술 방법의 선택이 아닌 수면에 대한 이해 가 전제되고, 수면장애의 여러 치료방법들 즉 지속적양압 술, 구강내장치(oral appliance) 등과 상호 보완 혹은 단 계적 틀을 이해하여야 성공적인 치료를 할 수 있다.

폐쇄성 수면무호흡증에 대한 수술은 상기도 폐쇄에 관 여하는 연조직 및 골격의 복잡한 상호작용, 음성과 연하 에 관여하는 해부학적 이해, 환자의 무호흡저호흡지수나 산소포화도가 심한 정도 등을 이해하고 수술방법과 범위 를 선택해야 한다.

일반적으로 폐쇄성 수면무호흡증의 환자에서는 여러 곳 의 폐쇄 부위가 관찰되기 때문에, 수술적 해결은 여러 폐 쇄 부위에 대해 복합적으로 이루어져야 한다.

\section{수술에 관한 치료 지침}

미국수면학회 실행위원회의 수술 치료에 대한 3가지 지침을 살펴보면 다음과 같다. 1) 중등도나 중증의 수면 무호흡증 치료는 지속적양압장치가 추천되며, 2) 수술 은 수면무호흡의 원인이 수술로서 교정 가능한 이상을 가진 환자에게 적용하며, 3) 또한 수술 치료는 다른 비 침윤적(noninvasive) 치료에 성공하지 못했거나 거부한 환자에게 또는 수술을 받을 수 있을 정도로 내과적으로 안정되고 수술 치료를 원하는 환자에게 적용된다.

수술 시 중요한 점은" 폐쇄성 수면무호흡증의 가장 기 본이 되는 치료는 지속적양압술”이라는 것과“ 수술 치료 의 목표는 완치"에 있다는 점이다. 따라서 수술 후 결과 는 지속적양압술의 결과와 비교할 수 있을 정도로 우수 하여야 한다.

\section{결 론}

이비인후과 의사가 코골이를 접했을 때 수술만을 생각 
하지 말고, 수면호흡장애의 한 증상으로서 코골이를 먼 저 고려하여, 환자가 수면호흡장애 중 어느 범주의 질환 (단순코골이, 상기도 저항증후군, 무호흡증) 에 속하는 가 를 결정한다. 그 다음 환자의 상태와 질환의 경중에 따 라 치료법을 선택하는데, 코골이만을 해결하기 보다는 주 간증상 및 심혈관계합병증이 오지 않을 치료법을 환자에 게 맞게 선택해야 한다.

중심 단어 : 수면호흡장애.

\section{REFERENCES}

1) Gastaut H, Tassinari CA, Duron B. Polygraphic study of the episodic diurnal and nocturnal (hypnic and respiratory) manifestations of the Pickwick syndrome. Brain Res 1996; $1: 167-86$.

2) Guilleminault C, Eldridge FL, Dement WC. Insomnia with sleep apnea: a new syndrome. Science 1973;181:856-8.

3) Guilleminault C, Riley R, Powell N. Obstructive sleep apnea and abnormal cephalometric measurements. Implications for treatment. Chest 1984;86:793-4.

4) Guilleminault $\mathrm{C}$, Tilkian A, Dement WC. The sleep apnea syndrome. Annu Rev Med 1976;27:465-84.

5) Guilleminault C, Eldridge F, Dement WC. Insomnia, narcolepsy and sleep apneas. Bull Physiopathol Respir 1972;8: 1127-38.

6) Carroll D. Nosology of the "Pickwickian syndrome". Bull Physiopathol Respir 1972;8:1241-7.

7) Tassinari CA, DallaBernadina B, Cirignotta F, Ambrosetto G. Apnoeic periods and the respiratory related arousal patterns during sleep in the Pickwickian syndrome: A polygraphic study. Bull Physiopathol Respir 1972;8:1087-102.

8) Guilleminault C, Dement WC. Sleep apnea syndromes and related sleep disorders. In Williams RL, Karacan I (eds): Sleep Disorders: Diagnosis and Treatment. New York, Wiley; 1978

9) Guilleminault C, Peraita R, Soupuet M, Dement WC. Apneas during sleep in infants: Possible relationship with SIDS Science 1975;190:677-9.

10) Carskadon MA, Harvey K, Dement WC, Guilleminault C, Simmons FB, Anders TF. Respiration during sleep in children. West J Med 1978;128:477-81.

11) Guilleminault C. Obstructive sleep apnea: the clinical syndrome and historical perspective. Med Clin North Am 1985; 69:1187-203.

12) AASM task Force. Sleep-related breathing disorders in adults: Recommendations for syndrome definition and measurement techniques in clinical research. Sleep 1999;22: 667-89.

13) Kump K, Whalen C, Tishler PV, Browner I, Ferrette V, Strohl $\mathrm{KP}$, et al. Assessment of the validity and utility of a sleepsymptom questionnaire. Am J Respir Crit Care Med 1994; 150:735-41.

14) Norton PG, Dunn EV. Snoring as a risk factor for disease: an epidemiological survey. Br Med J 1985;291:630-2.

15) Young T, Pepperd P, Dempsy J, Skatrud J, Weber S, Bader $\mathrm{S}$. The occurrence of sleep disordered breathing in African Americans and Caucasians. Am J Res Crit Care Med 1997; 155:1986-92.

16) Coleman RM, Roffwarg HP, Kennedy SJ, Guilleminault C, Cinque J, Cohn MA, et al. Sleep-wake disorders based on a polysomnographic diagnosis. A national cooperative study. JAMA 1982;247:997-1003.

17) Dealberto MJ, Ferber C, Garma L, Lemoine P, Alperovitch A. Factors related to sleep apnea syndrome in sleep clinic patients. Chest 1994;105:1753-8.

18) Khosla T, Lowe CR. Indices of obesity derived from body weight and height. Br J Prev Soc Med 1967;21:122-8.

19) Bixler EO, Kales A, Soldatos CR, Vela-Bueno A, Jacobs JA, Scarone S. Sleep apneic activity in a normal population. Res Commun Chem Pathol Pharmacol 1982;36:141-52.

20) Block AJ, Boysen PG, Wynne JW, Hunt LA. Sleep apnea, hypopnea and oxygen desaturation in normal subjects: a strong male predominance. N Engl J Med 1979;300:513-7.

21) Guilleminault C, Quera-Salva MA, Partinen M, Jamieson A. Women and the obstructive sleep apnea syndrome. Chest 1988;93:104-9.

22) Fletcher EC, DeBehnke RD, Lovoi MS, Gorin AB. Undiagnosed sleep apnea in patients with essential hypertension. Ann Intern Med 1985;103:190-5.

23) Richman RM, Elliott LM, Burns CM, Bearpark HM, Steinbeck KS, Caterson ID. The prevalence of obstructive sleep apnoea in an obese female population. Int J Obes Relat Metab Disord 1994;18:173-7.

24) Guilleminault C. Obstructive sleep apnea syndrome: $A$ review. Psychiatr Clin North Am 1987;10:607-21.

25) Baruzzi A, Riva R, Cirignotta F, Zucconi M, Cappelli M, Lugaresi E. Atrial natriuretic peptide and catecholamines in obstructive sleep apnea syndrome. Sleep 1991;14:83-6.

26) Findley LJ, Barth JT, Powers DC, Wilhoit SC, Boyd DG, Suratt PM. Cognitive impairment in patients with obstructive sleep apnea and associated hypoxemia. Chest 1986; 90:686-90.

27) He J, Kryger MH, Zorick FJ, Conway W, Roth T. Mortality and apnea index in obstructive sleep apnea. Experience in 385 male patients. Chest 1988;94:9-14.

28) National Commission on Sleep Disorders Research. Wake Up America: A National Sleep Alert (Vol 1). Submitted to the U.S. Congress; 1993.

29) Findley LJ, Weiss JW, Jabour ER. Drivers with untreated sleep apnea: A cause of death and serious injury. Arch Intern Med 1991;151:1451-2.

30) Stoohs RA, Guilleminault C, Itoi A, Dement WC. Traffic accidents in commercial long-haul truck drivers: the influence of sleep-disordered breathing and obesity. Sleep 1994; 17:619-23.

31) Guilleminault C, Stoohs R, Clerk A, Cetel M, Maistros P. A cause of excessive daytime sleepiness. The upper airway resistance syndrome. Chest 1993;104:78-7.

32) Guilleminault C, Stoohs R, Duncan S. Snoring (I). Daytime sleepiness in regular heavy snorers. Chest 1991;99:40-8.

33) Gleeson K, Zwillich CW, White DP. The influence of incr- 
easing ventilatory effort on arousal from sleep. Am Rev Respir Dis 1990;142:295-300.

34) Lofaso F, Coste A, Gilain L, Harf A, Guilleminault C, Goldenberg F. Sleep fragmentation as a risk factor for hypertension in middle-aged nonapneic snorers. Chest 1996;109: 896-900.

35) Guilleminault C, Robinson A. Sleep-disordered breathing and hypertension: past lessons, future directions. Sleep 1997;20:806-11.

36) Guilleminault C, Pelayo R, Leger D, Clerk A. Bocian RC. Recognition of sleep-disordered breathing in children. Pediatrics 1996;98:871-82.

37) AASM task Force. Sleep-related breathing disorders in adults: Recommendations for syndrome definition and measurement techniques in clinical research. Sleep 1999;22. 667-89.

38) Hoffstein V, Rubinstein I, Mateika S, Slutsky AS. Determi- nants of blood pressure in snorers. Lancet 1988;2:992-4.

39) Carlson JT, Hedner JA, Ejnell H, Peterson LE. High prevalence of hypertension in sleep apnea patients independent of obesity. Am J Respir Crit Care Med 1994;150:72-7.

40) Guilleminault C, Stoohs R, Kim YD, Chervin R, Black J, Clerk A. Upper airway sleep-disordered breathing in women. Ann Intern Med 1995;122:493-501.

41) Guilleminault C, Kim YD, Stoohs R. Upper airway resistance syndrome. Oral Maxillofacial Surg Clin of NA 1995; 7:301-14

42) Powell N, Riley R, Troell R, Li K, Blumen M, Guilleminault $\mathrm{C}$. Radiofrequency volumetric tissue reduction of the palate in subjects with sleep-disordered breathing. Chest 1998; 113:1163-74.

43) Silverberg D, Oksenberg A. Essential hypertension and abnormal upper airway resistance during the Sleep. Sleep 1997; 20:794-806. 